Vol. 6, Issue 5, May 2019

\title{
Steel Angles and Strips Jacketing of Existing RC Columns: A State of Art
}

\author{
Farjana Akter $^{1}$, Md. Hasnul Habib ${ }^{2}$ \\ Faculty, Dept. of Civil Engineering, Stamford University of Bangladesh, Dhaka-1219, Bangladesh ${ }^{1}$ \\ Faculty, Dept. of Civil Engineering, Stamford University of Bangladesh, Dhaka-1219, Bangladesh ${ }^{2}$
}

\begin{abstract}
Steel angles and strips jacketing method is the popular structural local strengthening technique for existing deficient RC columns. Although this strengthening technique is well accepted, limited research is carried on the actual strength and behaviour enhancement of the deficient RC columns due to the application of this particular steel jacketing method. This study primarily intends to review the experimental and numerical works on the steel angles and strips jacketing method used for deficient RC columns available in published literature. This study also intends to present the variables which have considerable influence on the strength and behaviour enhancement of the deficient RC columns for this structural local strengthening technique.
\end{abstract}

Keywords: Steel jacketing, Angles, Strips, Columns, Strength, Ductility, Confinement.

\section{INTRODUCTION}

Steel angles and strips jacket is made by fixing four angles around the four corner of the rectangular or square RC column vertically. The steel strips are welded horizontally to tie the angles and spaced at a rational spacing to form a steel case. The small gap left between the steel angle and the surface of the concrete column is then grouted to ensure full contact between the two of them. Fig. 1 shows the RC column strengthened by steel caging (without additional elements at the ends of the cage). This method does not require highly trained labour and is very easy to inspect. In addition, this method requires a limited space around the column section. Many researches showed that [1], [5], [6] and [17] if properly designed; this jacketing technique could enhance the global behaviour of the existing deficient RC columns. However, the real behaviour of the steel angles and strips jacketed RC columns is still remaining unidentified in the scientific community. A review is made on this intension to pinpoint the variables that have significant influence on improving of the behaviour of the jacketed RC columns and also to identify the domain of variables those have been less concentrated in the existing literature.

\section{COMPOSITE BEHAVIOR OF STEEL ANGLES AND STRIPS JACKETED RC COLUMN}

The behaviour of RC columns jacketed with steel angles and strips is primarily governed by two fundamental mechanisms. First, the degree of confinement is imposed on the concrete column from the externally fixed steel angles and strips jacket. The confinement pressure is produced in the core concrete due to the fixity provided by the steel cage against the concrete lateral expansion. According to the Montuori R. and Piluso V. (2009) [14], this pressure is applied to the confined concrete by arching nature. However, the measure of confining pressure in steel angle and strip jacketed $\mathrm{RC}$ columns is a complex mechanism since the pressure varies with the size and spacing of the lateral strips. This pressure also fluctuated along the length of strips [15]. Second, the amount of shear stresses is induced by the intermediate layer of grout material which stimulated slippage between the jacket and the concrete column. The variation of the shear stress is mainly dependent on the fluctuation of the surrounding confining pressures. The two mechanisms are illustrated in Fig. 2.

The failure of this type of steel jacketed RC column occurred when the jacket is no longer able to resist the compression applying on the column. Most of the researchers [17], [5] have shown that there are mainly two possible failure modes for steel angle and strip caged RC columns when the column is subjected under direct angle loading situation: (a) Failure due to yielding of the steel angles [Fig.3] (b) Failure due to yielding of the steel strips [Fig.4].

\section{LITERATURE REVIEW}

\section{A. Experimental Investigations}

Ramirez et al. (1999) [16] conducted experimental investigation on strengthened defected concrete columns. In the experiment, four angles were fixed at the corners of the column. Four steel plates were welded on to the angles. Two 


\title{
International Advanced Research Journal in Science, Engineering and Technology
}

\author{
Vol. 6, Issue 5, May 2019
}

bonding methods were used to connect the steel plates to the original defected concrete column. In the first method, the gap between the steel plates and concrete was injected using epoxy resin and fine sand. In the second method epoxy adhesive was used. It was concluded that the steel plate jacket with injection proved to be a more reliable method. Debonding of the plates was observed at low bearing load. The testing was ended with a sudden failure of the column. This was due to the low workability and brittleness of the used adhesion material.

Cirtek L. (2001) [3] conducted a test program consisted of 39 specimens measuring dimensions of $300 \times 300 \times 1500$ $\mathrm{mm}$. In this study steel angles and bandages were used in the strengthening scheme. The bandage of a fully banded column had continuous steel angles and the bandage of a partially banded column had non-continuous ones. The spacing and sectional area of steel strips, dimensions of angles and temperature of bandage activation were examined in this study. However, the main conclusion of this work was that the bandage columns enhanced its load-carrying capacity approximately by $55 \%$. A mathematical solution adopting an iterative method was presented at the end of the study.

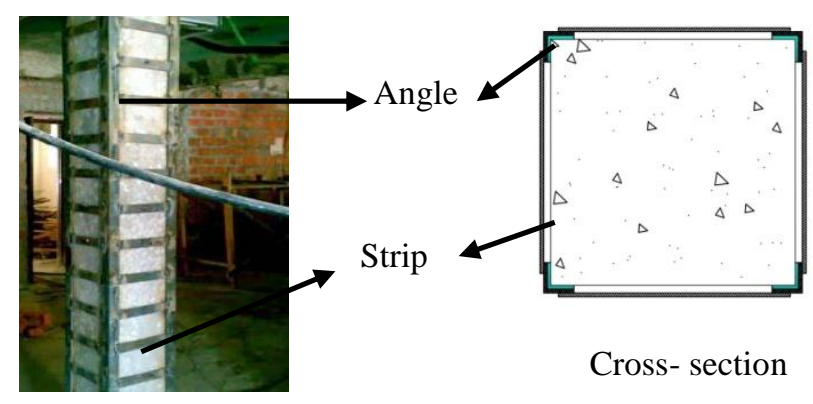

Fig. 1 Steel jacketing with angles and strips

Issa et al. (2010) [10] conducted experimental investigation to evaluate the behaviour of reinforced concrete columns strengthened externally with steel jacket or fiber composite under axial loads. The experimental program presented six rectangular reinforced concrete columns with the same dimension of $150 \times 200 \times 1200 \mathrm{~mm}$. The steel jacket consisted of four vertical angles and horizontal steel plates. The main parameter was the type of the external strengthening method. For the steel jacket the variables were the size of corner angles and the spacing between the steel plates. From the experimental study, it was concluded that increasing the area of corner steel angles and decreasing the spacing between the steel pattern plates of steel jackets increase the ultimate carrying capacity and ductility of strengthened columns.

Adam J. M. et al. (2009) [2] performed experiments on axially loaded RC columns strengthened by steel cages as well as numerical models to verify the obtained experimental results. The study considered these parameters: the size of the angles; the yield stress of the steel of the cage; the compressive strength of the concrete in the column; the size of the strips; the addition of an extra strip at the ends of the cage; and the friction coefficient between the layer of mortar and the steel of the cage. The obtained results of this parametric study were that the slippage between the steel cage and the column can be reduced by increasing the size of the strips due to the greater stiffness of the steel cage in the transverse direction. This improvement in confinement would also result in a better transmission of loads between the cage and the column by the shear stress mechanism.

Gimenez et al. (2009) [9] conducted full-scale tests on $70 \%$ preloaded RC columns strengthened with steel angle and strip cages. The number of strips at the ends of the columns was increased to prevent premature failure. The variables of the study were as follows: preloading state of the column before applying the strengthening method, fitting a capital at the joint between column head and the cage, the adhesive between the surface concrete and the column. It was concluded that the addition of two strips of a smaller size in the sections near the heads considerably improved the ultimate load and ductility of the column. It also helped the strengthened column to take place failure in the central section as well as to earn composite behaviour in these elements.

Areemit N. et al. (2013) [18] conducted experimental investigation on four identical specimens for determining the effectiveness of the strengthening technique for deficient RC columns using steel angles and battens. The specimens were selected resembling the typical RC columns used in low-rise buildings in Thailand. The concrete compressive strength of all the test specimens was same $(9 \mathrm{Mpa})$. In this study, the efficiency of different spacing patterns indicating to the different amount of steel of battens was investigated under axial loads. However, the significant enhancement in strength and ductility of the strengthened columns with low concrete strength was confirmed in this study. This study also showed that keeping maintain in the amount of steel battens same, the different spacing between 


\section{International Advanced Research Journal in Science, Engineering and Technology}

Vol. 6, Issue 5, May 2019

the battens demonstrated insignificant influence in improving of the load carrying capacity but this affects in the column ductility.

Khalifa and Tersawy (2014) [12] developed a practical based analytical model and designed an experimental program on seven low strength reinforced concrete columns. Two series of strengthening procedure were considered in this study. First series contained four steel angles and uniform interval of strips. Steel casing by four plates connected with or without dowels were included in the second series. This study concluded that the load carrying capacity could be enhanced up to $66 \%$ using steel angle and strip strengthening series. This capacity proved to be doubled with steel casing by four plate's series. This study also concluded that the increase of strip thickness and reduction on strip spacing resulted more effective strength and ductility than the increase in the steel angle dimensions. The presence of dowels exhibits comparatively slower failure of the column in steel casing techniques. Finally, the experimental and analytical results were compared and showed to be obtained a good agreement in them. The proposed analytical model accounted the composite action for concrete confinement and enhancement of the local buckling of the steel elements.

Tarabia and Albakry (2014) [17] studied the behaviour and efficiency of reinforced concrete square columns strengthened by steel angles and strips (steel cage). The main studied parameters were: size of the steel angles, strip spacing, grout material between column sides and angles, and the connection between the steel cage to the specimen head. Two different concrete strengths of $57.8 \mathrm{MPa}$ and $47.5 \mathrm{MPa}$ were also considered in this study. All the specimens were tested under concentric axial loads till failure. This study was concluded that jacketing by steel angles and strips proved to be a very efficient strengthening method. The gain in the axial load capacity of the strengthened columns was obtained from 1.35 to 2.10 of un-strengthened column. This gain was due to the confinement effect of the external steel cage, and the ability of the steel angle to resist an extensive part of the applied axial load. The failure in most of the strengthened specimens was due to the buckling of the steel angle followed by crushing of the original columns. The axial ductility of the strengthened column was also obtained to be increased by $50 \%$.

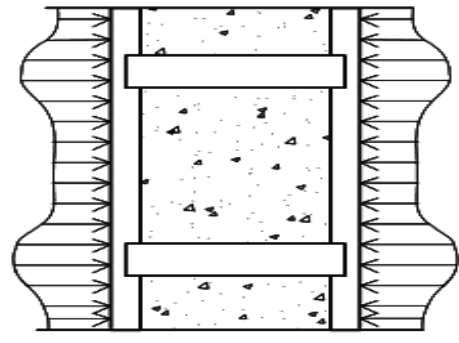

(a) By confinement

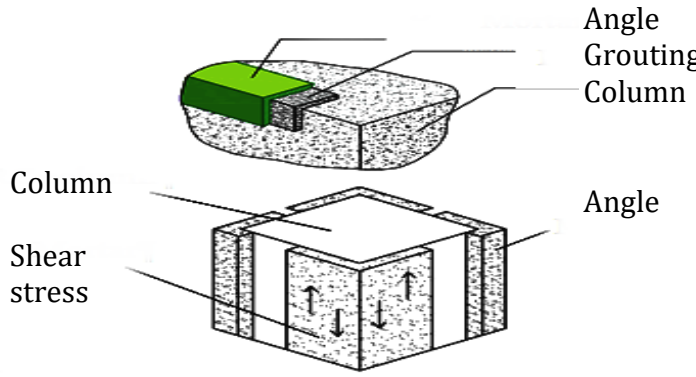

(b) By shear stresses

Fig. 2 Load transmission from steel angles and strips jacket to the column (Redrawn from Calderon et al. [5])

Belal et al. (2015) [3] performed experimental investigations on seven specimens under compressive axial loading. The specimens were strengthened with different steel jacketing configurations. Three different vertical steel elements (angles, channel and plates) were chosen with the same total horizontal cross sectional area. Three studied variables were: shape of main strengthening system (using angles, C-sections and plates), size and number of batten plates. This study concluded that angles and channels proved to be performed similarly, but steel plates resulted in less capacity for the column, due to the thinness of the plate. Batten plates had variable results based on which cross-section was used. The jacketing system with channels resulted higher strength than angles. But the angles were showed to be benefited more from improved confinement stress due to the discrete thicker plates. Additionally, the columns with angles experienced less deformation than from the other steel jacket/cage cross-sections.

Jodawat et al. (2016) [11] conducted an experiment program on fifteen specimens in order to evaluate performance of jacketing systems in increasing load carrying capacity of cracked members. Two types of jacketing system were used in the experiment: steel plate jacketing and angle batten jacketing. Six specimens were kept preloaded with $85 \%$ of failure load. It was concluded that the angle batten system had higher strength gain and better confining effect than the thin plate system. Also, greater increment in strength and axial deformation was achieved for no preloaded specimens.

Ezz-Eldeen (2016) [8] conducted both experimental and numerical investigation on fifteen column specimens in order to evaluate the efficiency of steel angles and strips jacketing method under eccentric loads. Four different eccentricities were used in the study. The twelve columns were divided in to three groups and strengthened them with three different angle set two same angles in compression side and two same angles in tension side separately. It was concluded that the increasing in covered area of the jacket increased the load carrying capacity of the strengthened columns. 


\section{International Advanced Research Journal in Science, Engineering and Technology}

Vol. 6, Issue 5, May 2019

Sen D. (2017) [7] performed an experimental investigation on six steel jacketed reinforced concrete columns under eccentric loads. The steel jacketing was consists of steel angles and steel strips. The results of this study indicated well performance of steel angle and strip jacketing scheme under both concentric and eccentric loading. The capacity enhancement was found about $240 \%$ under concentric loads compared to un-strengthened RC column. This study revealed that eccentricity reduces the ultimate capacity of steel cage jacketed RC column of about $15 \%$ when eccentricity changes from 0 to 0.45 of column width ratio. The eccentricity also obtained to change the ductile behavior of the jacketed columns.

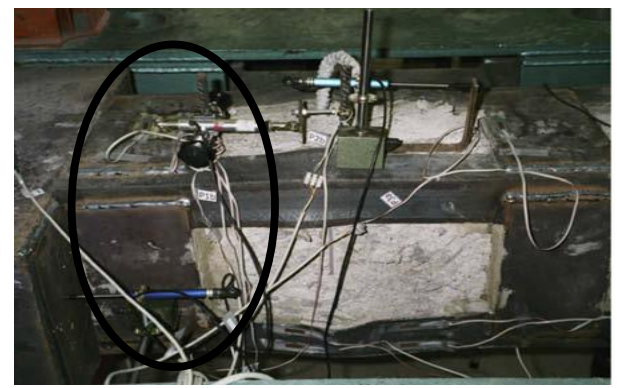

Fig. 3 Yielding of the angles (Retrieved from [5])

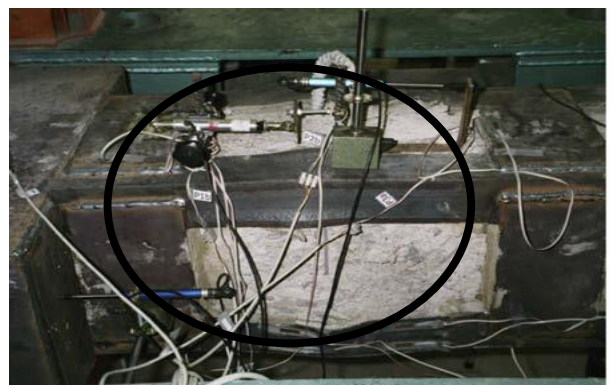

Fig. 4 Yielding of the strips(Retrieved from [5])

\section{B. Numerical Investigations}

Issa et al. (2010) [10] conducted numerical investigation to evaluate the behaviour of reinforced concrete columns strengthened externally with steel jacket or fiber composite under axial loads. The experimental program presented six rectangular reinforced concrete columns with the same dimension of $150 \times 200 \times 1200 \mathrm{~mm}$. The steel jacket consisted of four vertical angles and horizontal steel plates. The main parameter was the type of the external strengthening method. For the steel jacket the variables were the size of corner angles and the spacing between the steel plates. From the experimental study, it was concluded that increasing the area of corner steel angles and decreasing the spacing between the steel pattern plates of steel jackets increase the ultimate carrying capacity and ductility of strengthened columns.

Ezz-Eldeen (2016) [8] conducted numerical investigation using the commercial finite element program ANSYS version 15. This study constructed 3D FE model and showed good agreement with the experimental results. Then practical based strengthening dimension is proposed for different column load eccentricities. Columns with cross sectional areas ranging from $25 \times 35 \mathrm{~cm}$ to $25 \times 120 \mathrm{~cm}$ were numerically analyzed for this purpose and was presented in a tabular form for practical application.

Latheef and Sumayyath (2017) [13] conducted numerical analysis on nine RC column models. The columns were strengthened with steel angles and battens using 9 Taguchi models in the study. The numerical analysis was performed using ANSIS 15.8 finite element software. The intension of this study was to find out best model so that desired protection of life and damage can be protected. The deformation and stress could also be minimized. The used three varying parameters were: no of strips, thickness of strips and size of angles. Different combination of angle size and no of battens at different level were used in the model. This study concluded that an optimize desirable method combination of seven battens with $5 \mathrm{~mm}$ depth and angle with $35 \times 35 \times 5 \mathrm{~mm}$ size will give best result for life and damage.

Marco F. F. et al. (2018) [19] performed finite element analysis using ABAQUS CAE version 6.13. The FE modelling was built to reproduce the realistic compressive behaviour of partially steel-jacketed RC columns by means of the Concrete Damaged Plasticity (CDP) Model. However, this paper deal with the limitations of standard plasticity parameters for high confinement levels of CDP model and presented a strategy to fix the parameters of the CDP model analytically. In addition, a new strain hardening or strain softening function was developed for confined concrete coupled with the evaluation of the dilation angle including effects of confinement. Also, a simplified efficient modelling approach was proposed accounting the response of steel angle in compression. Finally, the prediction accuracy from the finite element model was compared with the available experimental data obtained from broad range of mechanical confinement ratio.

Chang S. K. (2018) [20] performed nonlinear numerical analysis in order to investigate the load-carrying capacity of high-strength CES-A columns [corner steel angles were encased in the concrete]. The effects of strain compatibility, 


\section{International Advanced Research Journal in Science, Engineering and Technology}

Vol. 6, Issue 5, May 2019

confinement effect of steel angles and transverse reinforcement, and local buckling of steel angles and longitudinal bar were considered in this study for numerical analysis. The studied parameters were: strength of concrete; strength, area, and compactness of steel angles; strength, thickness, and spacing of battens; eccentricity of axial load; and slenderness by varying column length and section. For verification, four experimental results of Kim et al. [21]; [22]; Eom et al. [23]; Hwang et al. [24] were utilized. The comparison showed good agreement with the experimental study results. Finally, this study proposed a simple approach for predicting the residual strength after first cover-spalling on the basis of the strain compatibility method.

Other researchers [3], [7] were also performed numerical investigations and showed fair agreement with the experimental results. The summary of the literature on nine selective variables are presented in TABLE I. This table presents the research on most influential variables along with minimal focused variables that are required to study in future research.

TABLE I: SUMMARY OF THE LITERATURE FOR SELECTIVE VARIABLES

\begin{tabular}{|c|c|c|c|c|c|c|c|c|c|}
\hline \multirow[t]{2}{*}{ Ref. } & \multicolumn{9}{|c|}{ Selective variables } \\
\hline & $\begin{array}{l}\text { Angle } \\
\text { steel ratio }\end{array}$ & $\begin{array}{l}\text { Angle } \\
\text { length }\end{array}$ & $\begin{array}{l}\text { Strips } \\
\text { spacing }\end{array}$ & $\begin{array}{l}\text { Strips } \\
\text { area }\end{array}$ & $\begin{array}{l}\text { Preloading } \\
\text { state }\end{array}$ & Eccentricity & $\begin{array}{l}\text { Concrete } \\
\text { strength }\end{array}$ & $\begin{array}{l}\text { Groutin } \\
\text { g } \\
\text { material } \\
\text { s }\end{array}$ & $\begin{array}{l}\text { Jacket } \\
\text { strengt } \\
\text { h }\end{array}$ \\
\hline$[16]$ & & & & & & & & $\mathbf{X}$ & \\
\hline [4] & $\mathbf{X}$ & $\mathbf{X}$ & $\mathbf{X}$ & $\mathbf{X}$ & & & & & \\
\hline [10] & $\mathbf{X}$ & & $\mathbf{X}$ & & & & & & \\
\hline$[2]$ & $\mathbf{X}$ & & & $\mathbf{X}$ & & & $\mathbf{X}$ & $\mathbf{X}$ & $\mathbf{X}$ \\
\hline [9] & & & & & $\mathbf{X}$ & & & $\mathbf{X}$ & \\
\hline [12] & $\mathbf{X}$ & & & & & & & & \\
\hline$[17]$ & $\mathbf{X}$ & & $\mathbf{X}$ & & & & $\mathbf{X}$ & $\mathbf{X}$ & \\
\hline [3] & & & $\mathbf{X}$ & & & & & & \\
\hline$[11]$ & & & & & $\mathbf{X}$ & & & & \\
\hline [8] & $\mathbf{X}$ & & $\mathbf{X}$ & & & $\mathbf{X}$ & & & \\
\hline [13] & $\mathbf{X}$ & & $\mathbf{X}$ & $\mathbf{X}$ & & & & & \\
\hline [7] & & & & & & $\mathbf{X}$ & & & \\
\hline [18] & & & $\mathbf{X}$ & & & & & & \\
\hline$[20]$ & $\mathbf{X}$ & & $\mathbf{X}$ & $\mathbf{X}$ & & $\mathbf{X}$ & $\mathbf{X}$ & & $\mathbf{X}$ \\
\hline
\end{tabular}

\section{IV.CONCLUSION}

In light of the above literature discussion and review, the following conclusions are drawn tentatively in this study.

1. The method of steel jacketing with angles and strips is a promising strengthening method for improving in global behaviour of the existing deficient square or rectangular RC columns.

2. Numerous experimental and numerical research works are based on accounting the multiple variables of jacketed angle steel ratio, strip size and spacing, grouting materials, length and location of jacket, column loads eccentricity, strength of steel jacket and strength of concrete of the deficient RC column. It is confirmed from the researches that the mentioned variables have significant influence on improving of column global behaviour under directly or indirectly loaded angle case.

3. However, the mentioned influential variables are required to investigate in the domain of column preloading condition since the numbers of test data on these variables are very limited for the existing column preloading state. In real scenario, the columns must be initially loaded before jacketing.

4. The research works are also found to investigate the behaviour of steel jacketed RC columns for monotonic loading situations only. Further research is required to study the behaviour of steel angles and strips jacketed RC columns under cyclic and dynamic loadings situation.

\section{REFERENCES}

[1] [Badalamenti,V., Campione, G., and Mangiavillano, M. L. "Simplified model for compressive behavior of concrete columns strengthened by steel angles and strips," ASCE Journal of Engineering Mechanics, vol. 136, no. 2, pp. 230-238, Feb. 2010. DOI:10.1061/(ASCE)em.19437889.0000069

[2] Adam J.M., Ivorra S., Pallarés F.J., Giménez E, and Calderón P.A. , “Axially loaded RC columns strengthened by steel caging finite element modeling," Construction and Building Materials, vol. 23, no. 6, 2009, pp. 2265-76, Jan. 2009. DOI:10.1016/j.conbuildmat.2008.11.014. 


\title{
International Advanced Research Journal in Science, Engineering and Technology
}

\author{
Vol. 6, Issue 5, May 2019
}

[3] Belal M. F., Mohamed H. M., and Morad S. A., "Behavior of reinforced concrete columns strengthened by steel jacket," Housing and Building National Research Center (HBRC) journal, vol. 11, no.2, pp. 201 - 212, Aug. 2015. DOI: 10.1016/j.hbrcj.2014.05.002

[4] Cirtek L., "RC columns strengthened with bandage-experimental program and design recommendations," Construction and Building Materials, vol. 15, no.8, pp. 341-349, Dec. 2001. DOI: 10.1016/s0950-0618(01)00015-0

[5] Calderón, P. A., Adam, J. M., Ivorra, S., Pallarés, F. J., and Giménez, E., "Design strength of axially loaded RC columns strengthened by steel caging," Materials and Design, vol. 30, no. 10, pp. 4069-4080, Dec. 2009.DOI: 10.1016/j.matdes.2009.05.014

[6] Campione G., (2012). "Strength and ductility of R.C. columns strengthened with steel angles and battens," Construction and Building Materials, vol. 35, pp. 800-807. Jun. 2012. DOI: 10.1016/j.conbuildmat.2012.04.090

[7] Devasis, S. (2017), "Behaviour and strength of RC columns retrofitted with steel angles and strips under eccentric axial loads", M. Sc. Dissertation, Bangladesh University of Engineering University, Dhaka.

[8] Ezz-Eldeen, H. A., "Steel jacketing technique used in strengthening reinforced concrete rectangular columns under centricity for practical design applications," International Journal of Engineering Trends and Technology, vol. 35, no.5, pp. 195-204, May 2016.

[9] Giménez, E., Adam, J. M., Ivorra, S., Moragues, J. J., and Calderón, P.A. (2009). "Influence of strips configuration on the behaviour of axially loaded RC columns strengthened by steel angles and strips.” Materials and Design, vol.30, pp. 4103-4111, May 2009.

[10] Issa M.S., Elzeiny S.M., Aly E.H., Metwally I.M.. "Investigation of reinforced concrete columns strengthened externally with steel jacket and fiber composite," Scientific Journal of the National Water Research Center, vol. 48, pp. 51-68, Oct. 2010.

[11] Jodawat, A., Arihant, P. A., Bhushan, M. B.,Pawar K., Patwa S., Sahu Y., and Jain I., "Retrofitting of reinforced concrete column by steel jacketing," International Journal of Engineering Research and Application, vol. 6, no. 7 (1), pp. 01-05. Jul. 2016

[12] Khalifa, E. S., and Al-Tersawy, S. H. "Experimental and analytical behavior of strengthened reinforced concrete columns with steel angle and strip.” Int J Adv Struct Eng, vol. 6, no. 61, June 2014, pp.1-14. DOI 10.1007/s40091-014-0061-6

[13] Latheef, A., and Sumayyath, M. M.,"Study of seismic response of column strengthened by angles and strips and optimizing the parameters for deformation, stress, life and damage," International Journal of Innovative Science, Engineering \& Technology, vol. 4, no. 4, pp. 235-240, Apr. 2017.

[14] Montuori R. , Piluso V.,"Reinforced concrete columns strengthened with angles and battens subjected to eccentric load," Engineering Structures, vol. 31, no. 4, pp. 539-550. Feb. 2009. DOI:10.1016/j.engstruct.2008.10.005

[15] [Nagaprasad, P., Sahoo, D. R., and Rai, D. C. "Seismic strengthening of RC columns using external steel cage." Earthquake Engineering and Structural Dynamics, vol. 38, no.14, pp.1563-1586, Apr. 2009. DOI: 10.1002/eqe.917

[16] Ramiez J.L., Blrcena J.M., Urreta J.I., Shchez J.A. "Efficiency of short steel jackets for strengthening square section concrete columns." Construction and Building Materials. Vol. 11, no. (5-6), pp. 345-352, Mar. 1999. DOI: 10.1016/S0950-0618(97)00056-1.

[17] Tarabia, A. M., and Albakry, H. F. "Strengthening of RC columns by steel angles and strips," Alexandria Engineering Journal, vol. 53, no. 3, pp. 615-626, Sep. 2014. DOI: 10.1016/j.aej.2014.04.005

[18] Areemit N., Faeksin N., Niyom P. and Phonsak P. "Strengthening Of Deficient Rc Columns By Steel Angles and Battens Under Axial Load." Proceedings of the Thirteenth East Asia-Pacific Conference on Structural Engineering and Construction (EASEC-13), Sapporo, Japan, Sep. 1113, 2013, I-5-6.

[19] Marco F. F., Liborio C. and Fabio D. T., "FE modeling of Partially Steel-Jacketed (PSJ) RC columns using CDP model." Computers and Concrete, vol.22, no. 2, pp. 143-152, Aug. 2018. DOI: 10.12989/cac.2018.22.2.143

[20] Chang-S. K., and Hyeon-Jong H. "Numerical Investigation on Load-carrying Capacity of High-strength Concrete-encased Steel Angle Columns." International Journal of Concrete Structures and Materials. Vol. 12, no. 1, pp. 1-17, Dec 2019. DOI 10.1186/s40069-018-0238-7

[21] Kim, C. S., Park, H. G., Chung, K. S., \& Choi, I. R. "Eccentric axial load capacity of high-strength steel—concrete composite columns of various sectional shapes.” Journal of Structural Engineering, vol.140, no. 4, Apr. 2014, DOI: 10.1061/(ASCE)ST.1943-541X.0000879

[22] Kim, C. S., Park, H. G., Lee, H. J., Choi, I. R., \& Chung, K. S."Eccentric axial load test for high-strength composite columns of various sectional configurations." Journal of Structural Engineering, vol. 143, no. 8, 2017.

[23] Eom, T. S., Hwang, H. J., Park, H. G., Lee, C. N., \& Kim, H. S. "Flexural test for steel-concrete composite membersusing prefabricated steel angles.” Journal of Structural Engineering, vol. 140, no. 4, 2014.

[24] Hwang, H. J., Eom, T. S., Park, H. G., \& Lee, S. H. "Axial load and cyclic load tests for composite columns with steel angles." Journal of Structural Engineering, vol. 142, no. 5, 2016.

\section{BIOGRAPHIES}

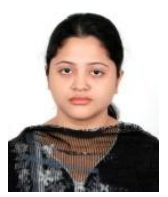

Farjana Akter, Graduated in Civil Engg. from Stamford University Bangladesh and Post-Graduaded in M.Sc. in Civil Engg. (Structural) from BUET, Bangladesh. Currently, she works as Senior Lecturer in the Dept. of Civil Engg. of Stamford University Bangladesh. Her research interests include: Civil Engg. materials and testing, Retrofitting, FEM etc.

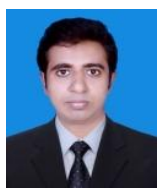

Md. Hasnul Habib, Graduated in Civil Engg. from RUET, Bangladesh and currently studying in M.Sc. in Civil Engg. (Structural) at BUET, Bangladesh. At present, he works as Lecturer in the Dept. of Civil Engg. of Stamford University Bangladesh. 